\section{Truckee-Carson Program}

After decades of litigation and negotiation, the Truckee-CarsonPyramid Lake Water Rights Settlement Act was passed in 1990. The law provides a foundation for developing operating criteria for interstate allocation of water to meet demands for municipal, irrigation, fisheries and wildlife, and recreational uses, as well as to meet water-quality standards, in the approximately 7,000 square-mile Truckee River and Carson River Basins of eastern California and western Nevada (fig. 1). The Truckee-Carson Program of the U.S. Geological Survey (USGS) is assisting the U.S. Department of the Interior in implementing the act. The program has the following objectives:

- Consolidate streamflow and water-quality data from several agencies into a single data base;

- Establish new streamflow and water-quality gaging stations for more complete water-resources information and more consistent support of river operations; and

- Build, calibrate, test, and apply interbasin hydrologic computer models to support efficient water-resources planning, management, and allocation.

Berris (1996) and Hess (1996) describe the current progress of the Truckee-Carson Program objectives.

\section{Hydrological Simulation Program-Fortran}

A computer model simulating storage and flow of the water in the Truckee River and Carson River Basins and in the Truckee Canal is being developed to help meet the third objective of the Truckee-Carson Program. The model, based on the Hydrological Simulation Program-Fortran (HSPF; see Bicknell and others, 1993), simulates reservoir and diversion operations to analyze alternative water-management scenarios.

This fact sheet summarizes some of the capabilities that were added to HSPF to simulate complex river diversion operations in the upper Carson River Basin in eastern California and western Nevada. Examples include river diversion operations based on existing and possible agricultural or municipal and industrial demands, and operations used to divert water and fill reservoirs. River diversion operations are the distribution of waters based on legal decrees that govern the right to beneficial use of water established in accordance with the western system of appropriative water rights.' In this summary, simplified or isolated examples are used to illustrate specific operations that can be represented by

${ }^{1}$ Appropriative legal water rights in the Nevada parts of the Carson River and Truckee River Basins are based on the concept of "first in time, first in right." This means the first person to take a quantity of water and put it to beneficial use has a higher priority of right than a subsequent appropriative user. An appropriator usually is assigned a priority date (date of established water right). This date in relation to dates assigned to other users for the use of the same source of water is significant when the quantity of available water is insufficient to meet all the needs of all the legal users.

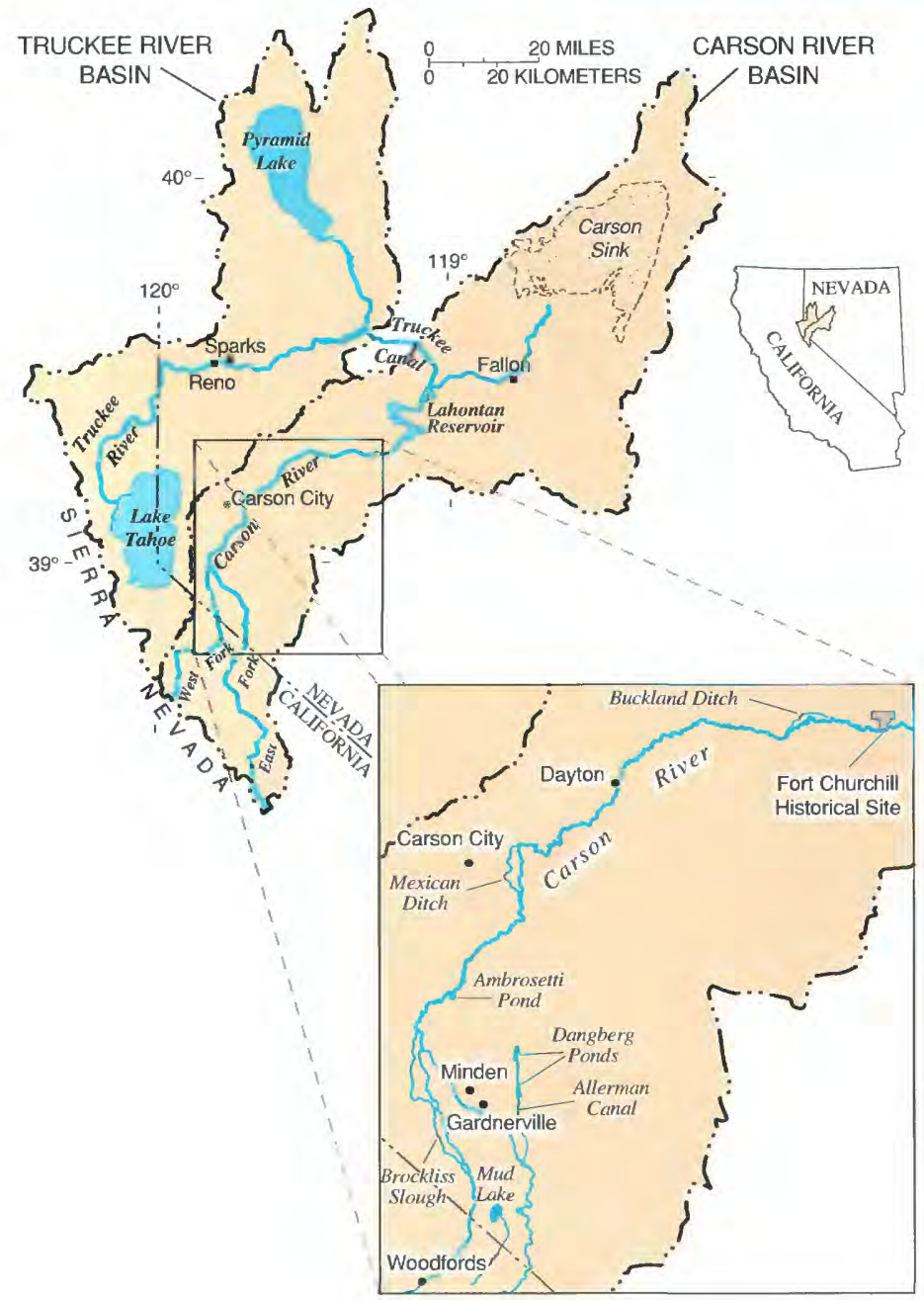

Figure 1. Geographic and hydrologic features of the Truckee River and Carson River Basins.

HSPF. Actual day-to-day system management or simulation requires consideration of present and forecast flow conditions at various locations in the river basin as well as compliance with numerous legal agreements, legal decrees, and demands.

The HSPF program uses water-quantity and water-quality information to simulate hydrologic processes on pervious and impervious land surfaces, in the soil profiles, in drainage networks, and in well-mixed lakes and reservoirs. The model simulations described in this fact sheet use only those parts of HSPF involved in routing streamflow and in determining diversion operations.

HSPF was chosen to simulate Carson River diversion operations primarily because it can (1) simulate streamflow continuously over time, including periods of storm runoff and low flows, (2) simulate streamflow at a variety of time steps, including daily and hourly, (3) simulate the hydraulics of complex natural and man-made drainage networks, (4) produce simulation results for many locations along the river and its tributaries, and (5) compute a detailed water budget that accounts for inflows and diversions as well as different categories of water in the river and associated reservoirs. 


\section{HSPF Simulations of Carson River Diversion Operations}

HSPF uses conditional logic to simulate river diversion operations (Tom Jobes, Aqua Terra Consultants, written commun., 1995). In the upper Carson River Basin, ditch headgates along the East Fork Carson, West Fork Carson, and Carson Rivers are operated according to complex regulations and legal decrees that specify conditions for the use of water. Conditions that are evaluated during simulations include the time of year; reservoir stage, reservoir storage, or volume of a given water category (or ownership $)^{2}$ in a reservoir; streamflow magnitude at a given location; and fulfillment of water demands. HSPF models operations by evaluating specifications of these conditions and simulating the resultant operations.

The following examples show results from preliminary HSPF simulations of Carson River diversion operations based on selected existing legal decrees and regulations. These examples are intended only to illustrate how HSPF can simulate operations rather than to convey citable or quantitative model results.

\section{Diversion Operations Based on Existing Agricultural or Municipal and Industrial Demands}

The Alpine Decree (U.S. District Court, 1980) separates the upper Carson River Basin into eight segments. Each segment is operated autonomously with respect to diversions. For lands within a segment, demand was tabulated according to (1) the consumptive-use duty ${ }^{3}$ specified as $4.5,6.0$, or 9.0 acre-feet per acre for agricultural demands and the net consumptive-use duty of 2.5 acre-feet per acre for municipal and industrial demands, and (2) the water-righted acreage (Garry Stone, U.S. District Court, written commun., 1995) using current (1995) rights. In HSPF each demand is separated according to priority date, and the individual demands are grouped according to the ditch serving the lands. During irrigation season, which typically is April through September, HSPF conditional logic compares the flow at the upstream boundary of the segment with the total amount of demands, based on priority dates, that could be satisfied. Those agricultural or municipal and industrial demands capable of being satisfied under current flow conditions are diverted from the mainstem Carson River to the appropriate ditch.

\footnotetext{
${ }^{2} \mathrm{~A}$ category of water is any block of water that is individually accounted for in an observed or simulated water budget. A single river, reservoir, lake, or diversion ditch may contain several categories. Water within a category may have specific ownership, such as "privately owned stored water," or have a designated use, such as "pooled water" (used to meet a minimum-flow requirement known as Floriston rates).

${ }^{3}$ The consumptive-use duty for agriculture is the total volume of irrigation water required to mature a particular type of crop. The duty is the amount of water supplied to the land with transmission losses, not the volume of water actually consumed by the plants. The consumptive-use duty for municipal and industrial has no transmission losses.
}

An HSPF simulation that illustrates how diversion operations of the Carson River are used to satisfy existing agricultural demands for the Buckland Ditch near Fort Churchill is shown in figure 2. Flow is available to satisfy all Buckland Ditch water rights from April to mid-July. Thereafter, flow in the river is less than the amount required to satisfy all Buckland Ditch rights, which is about 23 cubic feet per second. Thus, the ditch diversion is reduced, satisfying increasingly fewer senior rights until late September when no rights can be served by the prevailing flow in the river.

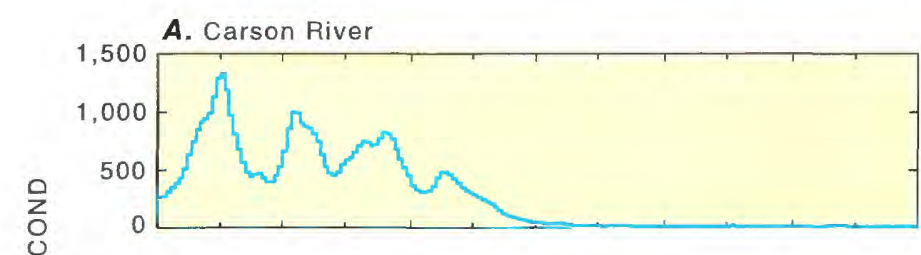

B. Buckland Ditch simulated

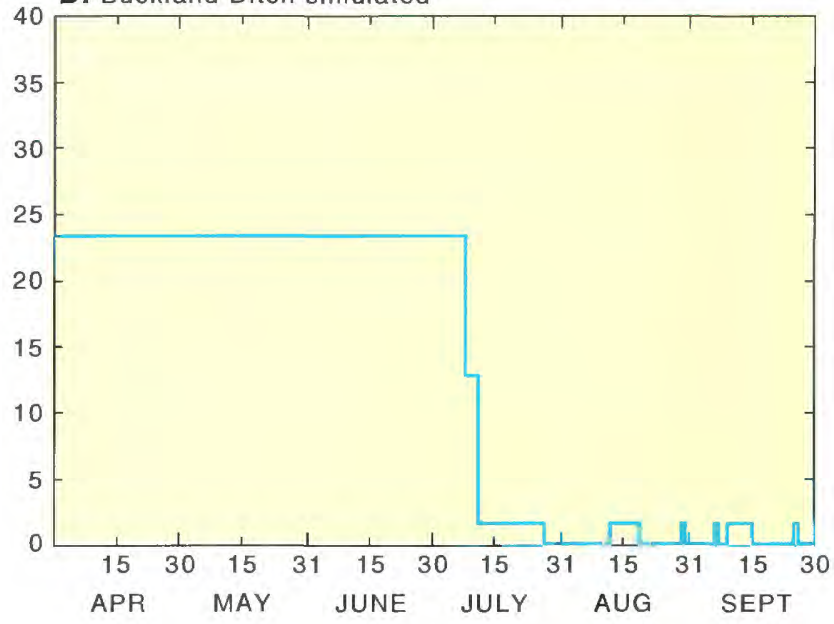

Figure 2. Carson River flow and diversion operations, Buckland Ditch. (A) Carson River flow above the ditch headgate, and $(\boldsymbol{B})$ HSPF river diversions using existing agricultural water rights to simulate flow in Buckland Ditch.

An HSPF simulation that illustrates diversion operations of the East Fork Carson River to the Allerman Canal near Gardnerville is shown in figure 3 . This particular simulation incorporates conditional logic that partitions flows according to the Alpine Decree. which defines diversion operations for existing agricultural demands during the irrigation season. For the period from April 1 to late July, Allerman Canal diversions are determined from operations based on agricultural demands. From late July through September, when flow in the East Fork Carson River is less than 200 cubic feet per second, one-third of the river flow is diverted into the canal and two-thirds of the flow remains in the river. 


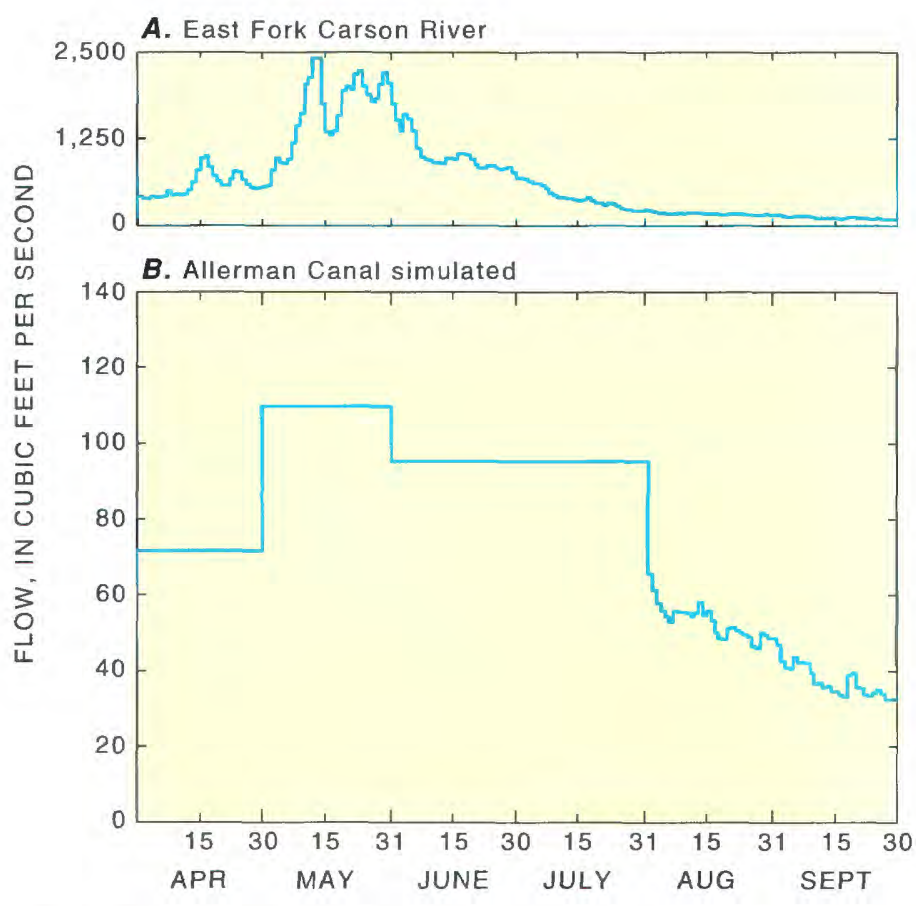

Figure 3. East Fork Carson River flow and diversion operations, Allerman Canal. (A) East Fork Carson River flow, and $(\boldsymbol{B})$ HSPF river diversions using the Alpine Decree rules to simulate flow in Allerman Canal.

An HSPF simulation that illustrates diversion operations of the West Fork Carson River to the Brockliss Slough is shown in figure 4. HSPF conditional logic partitions the West Fork flow according to the Anderson-Bassman Decree rule of rotation. ${ }^{4}$ For the period from June 1 to mid-June, water is sufficient to satisfy all rights and no rotation occurs. From mid-June through September, when flow in the West Fork Carson River is less than about 180 cubic feet per second, the river is considered to be "in regulation" and weekly rotation of diversions between California and Nevada segments of the river causes flows to fluctuate. Although not illustrated, the same conditional logic partitions the West Fork Carson River flow for water rights according to the Price Decree.

\section{Diversion Operations Used to Fill Reservoirs}

Diversion operations to fill off-river reservoirs also are simulated by HSPF using conditional logic. Water-storage rights defined by the Alpine Decree allow the filling of Mud Lake during the non-irrigation season. HSPF determines when and how much flow is diverted to satisfy Mud Lake water-storage rights for future demands. Simulated Mud Lake water storage from October 15 to December 31, shown in figure 5, reaches the legal limit of 3,172 acre-feet on about December 20. The lake storage remains constant for the period December 20-31, except for a slight increase in storage due to localized precipitation. Although not illustrated, similar conditional logic based on legal decrees is used by HSPF to fill Dangberg Ponds and Ambrosetti Pond in the Carson River Basin.

\footnotetext{
${ }^{4}$ Rotation is water delivery where a constant supply flow is rotated to
} different users at varying times.

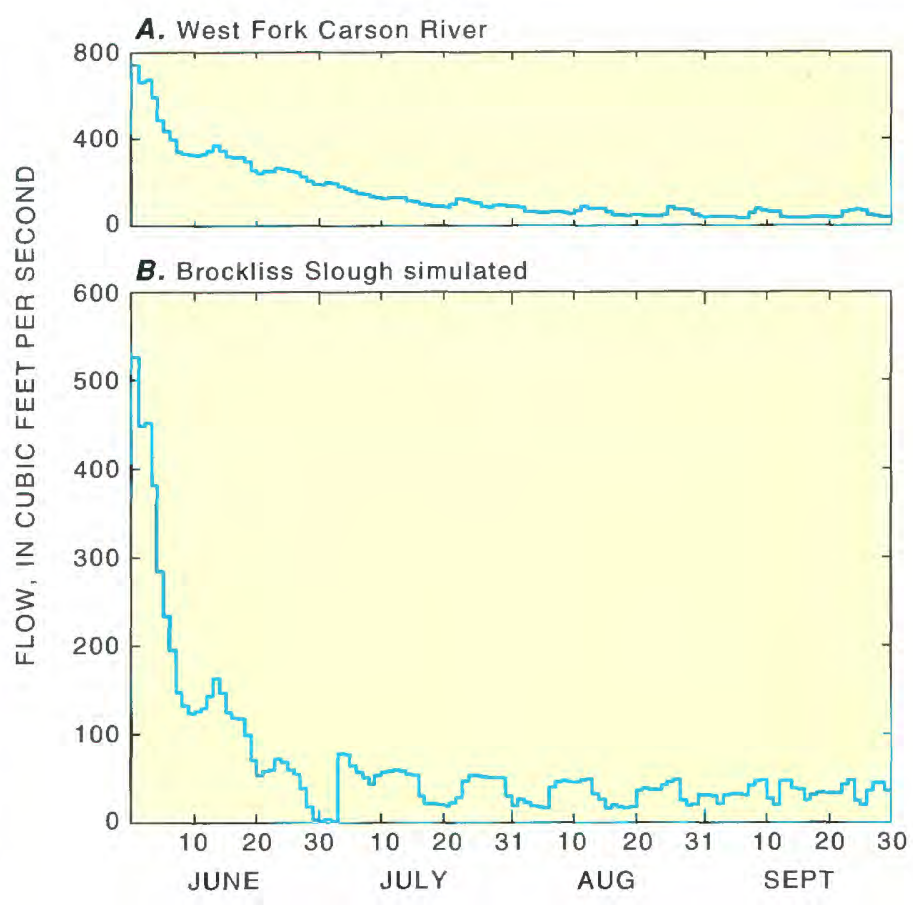

Figure 4. West Fork Carson River flow and diversion operations, Brockliss Slough. (A) West Fork Carson River flow, and $(\boldsymbol{B})$ HSPF river diversions using the Anderson-Bassman Decree rule of rotation to simulate flow in Brockliss Slough.

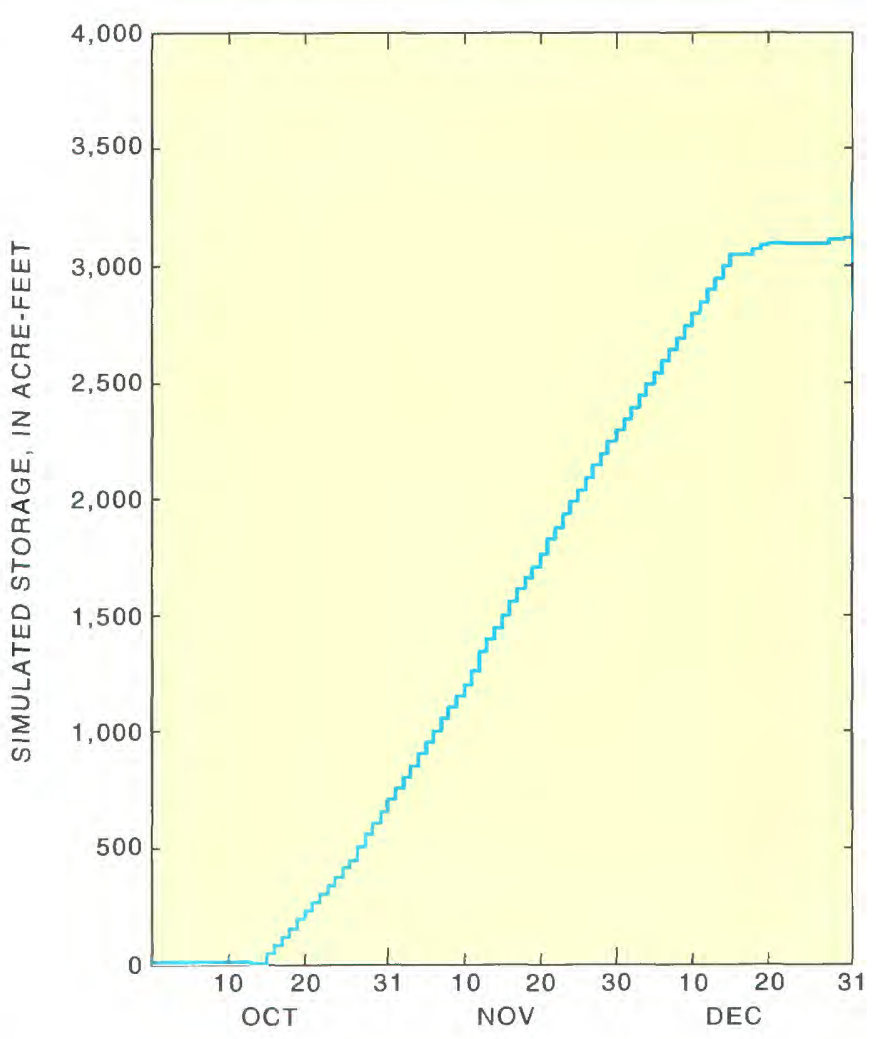

Figure 5. HSPF simulation of storage in Mud Lake based on the Alpine Decree. 


\section{Diversion Operations Based on Possible Agricultural or Municipal and Industrial Demands}

HSPF simulations can be used to demonstrate how potential changes in agricultural or municipal and industrial water demands may affect downstream flows. For example, figure 6 shows the changes in diversions from the Carson River into Mexican Ditch that would occur if 492.3 acres of the 838.3 acres of agricultural water rights served by the ditch were to be converted from an agricultural demand to a municipal and industrial demand. Because of the difference between agricultural, and municipal and industrial duties (in this case 6.0 and 2.5 acre-feet per acre, respectively), the agricultural diversion rate decreases from 26.0 to 18.8 cubic feet per second during the irrigation season. The resultant downstream effect on Carson River flows near Fort Churchill from July through October is shown in figure 6. The simulation indicates that only about half of the 1,700 acre-feet per year of potential water savings resulting from the change in water use would be realized at Fort Churchill. In this simulation, the remainder of the water left in the river as a result of the reduced Mexican Ditch diversions was either consumed by phreatophytes or used for irrigation by previously unsatisfied water-rights holders in the river between Mexican Ditch and Fort Churchill.

\section{Further Model Development}

The Carson River operations model is just one modular component in a comprehensive computer-modeling system being developed by the USGS Truckee-Carson Program. The modeling system integrates data management and analyses (Bohman and others, 1995) with the basin-operations model including reservoir

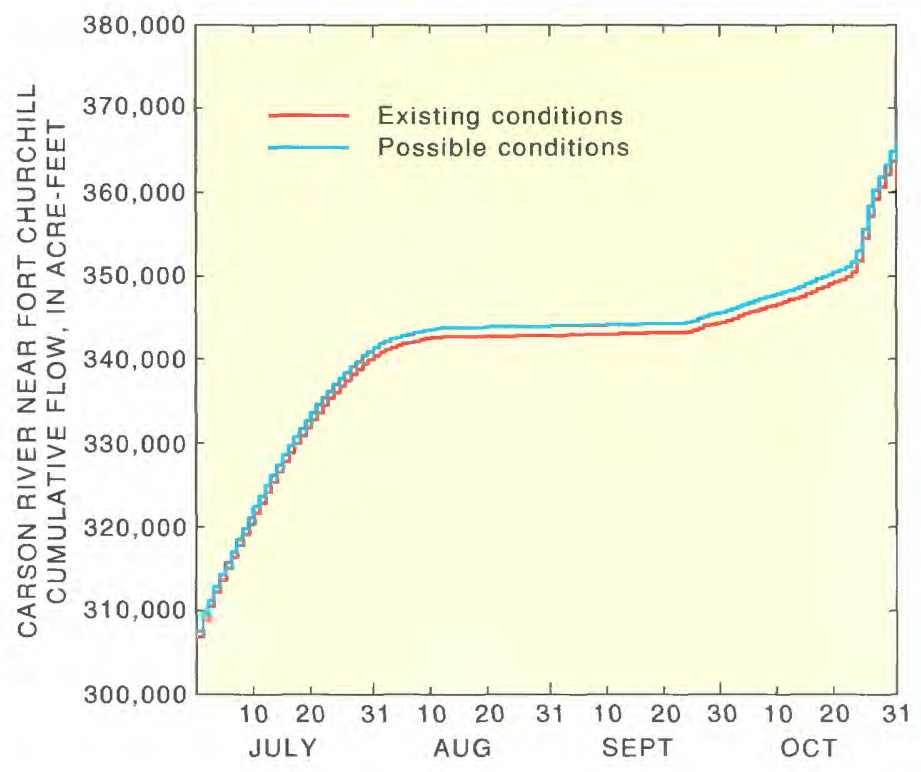

Figure 6. HSPF simulation of changes to Carson River flow near Fort Churchill that would occur if a portion of the water in Mexican Ditch were diverted for municipal and industrial water demands rather than for agricultural. operations (Berris and others, 1996) and physically based hydrologic models that simulate flow, stream temperature, precipitationrunoff relations, and selected water-quality characteristics. The modeling system, when calibrated and tested, will provide the tools necessary for modelers and those officials responsible for water-related policy to examine many interrelated hydrologic and resources-management issues for the Truckee River and Carson River Basins. The ability to simulate alternative management scenarios and compare the simulation results will help users understand the effects of change in river/reservoir operations, land use, water-rights transfers, and irrigation practices on the quantity and quality of water throughout the system.

-Glen W. Hess

\section{References Cited}

Berris, S.N., 1996, Daily flow-routing simulations for the Truckee River, California and Nevada: U.S. Geological Survey Water-Resources Investigations Report 96-4097, 83 p.

Berris, S.N., Hess, G.W., and Cartier, K.D., 1996, Simulation of selected reservoir operations in the Upper Truckee River Basin, California, U.S. Geological Survey Fact Sheet FS-082-96, 4 p.

Bicknell, B.R., Imhoff, J.C., Kittle, J.L., Donigan, A.S., and Johanson, R.C., 1993, Hydrological Simulation ProgramFortran-User's manual for release 10: U.S. Environmental Protection Agency Report EPA/600/R-93/174, 660 p.

Bohman, L.R., Berris, S.N., and Hess, G.W., 1995, Interactive computer program to simulate and analyze streamflow, Truckee and Carson River Basins, Nevada and California: U.S. Geological Survey Fact Sheet FS-165-95, 4 p.

Hess, G.W., 1996, Progress report on daily flow-routing simulation for the Carson River, California and Nevada: U.S. Geological Survey Open-File Report 96-211, 41 p.

U.S. District Court, Nevada, 1980, The United States of America v. Alpine Land and Reservoir Co., et al., Findings of fact, conclusions of law, tabulation and administrative provisions: Final Decree, Civil No. D-183 BRT, 18 p.
Public Information Assistant U.S. Geological Survey 333 W. Nye Lane, Rm 203 Carson City, NV 89706 tel. (702) 887-7649 fax (702) 887-7629 usgsinfo_nv@usgs.gov 